\section{OPEN JOURNAL SYSTEMS}

ISSN:2237-2202
Available on line at Directory of Open Access Journals

Journal of Hyperspectral Remote Sensing v.7, n.7 (2017) 378-388

www.periodicos.ufpe.br/revistas/jhrs
Journal of Hyperspectral Remote Sensing

\title{
Agronomic variability of the oleaginous plant in the presence and absence mulching in the semiarid
}

\author{
Liliane C. Pinheiro ${ }^{*}$, Abelardo A. A. Montenegro ${ }^{* * *}$, João L. M. P. de Lima ${ }^{* * *}$ \\ * Doctoral student in Agricultural Engineering; Federal Rural University of Pernambuco - UFRPE, Av. D. Manoel de Medeiros, \\ s/n. Dois Irmãos, Recife - PE - Brazil. Email: lilianecp@ yahoo.com.br (Corresponding author) \\ * Professor; Department of Agricultural Engineering; UFRPE. Email: abelardomontenegro666@ gmail.com \\ ${ }^{* * *}$ Professor; Department of Civil Engineering, Faculty of Science and Technology of the University of Coimbra-FCTUC
}

Received 13 June 2017; accepted 30 October 2017

\begin{abstract}
Spatial variability characterization is important to identify areas with different potential for crop production. The objective of the present study is to evaluate the impact of presence and absence of mulching, using spatial variability in height and diameter of unconventional oilseed crop (Moringa oleifera Lam.), in an alluvial valley in the semiarid of Pernambuco State. The study was carried out at the Irrigated Agriculture Station of Parnamirim (EAIP), Advanced Unit of the Federal Rural University of Pernambuco. Two neighboring irrigated areas were selected, an area containing vegetative conservation practice using coconut dust as mulching (PM), with density is $8 \mathrm{t}^{\mathrm{h}} \mathrm{ha}^{-1}$, and another area with mulching (AM). The variables plant height and stem diameter were submitted to descriptive statistical analysis, semivariogram adjustment and analysis of variance for the samplings, besides the range measurement (a). The average values for both variables height and stem diameter with PM presented higher values, relative to the AM. The degree of spatial dependence showed that there is a strong dependence on plant height in both treatments. In general, the use of conservation practice with the application of mulching has promoted agronomic improvement, which may led more favorable development of the Moringa oleifera Lam cropping, which may mitigate climate change effects.

Keywords: Mulching, conservation practice, geostatistics.
\end{abstract}

\section{Introduction}

The knowledge of the spatial variability contributes to the proper and precise management of the soil, since it allows identifying zones that require different management, reducing environmental impacts and increasing the efficiency of the crops (Santos et al., 2012). Geostatistics is a technique that allows the characterization of spatial variability using kriging and co-kriging methods for mapping, thus improving the understanding of eco-geomorphological variables.

In this context, a number of studies have been intensified in recent years by several researchers (Fontes Júnior et al., 2012; Montenegro et al., 2013; Silva et al., 2014; Ceddia et al., 2015; Melo and Montenegro, 2015; Almeida et al., 2016). For these researchers, studies related to the variability of chemical and physical attributes are important tools to identify areas with greater ability for crops, for the management of groundwater resources, and for proper soil management.

Conservation practices promote improved soil quality and can contribute to mitigating climate change
(Lal, 2011). The use of mulching in the soil is considered a vegetative conservation practice, because it has both agronomic and environmental preservation advantages, recommended in the semiarid regions by reducing soil water losses, surface erosion, and contribution to improving crop performance.

The presence of vegetation cover on the soil surface provides several benefits to the agroecossystem, for enabling the reduction of weed infestation, control the temperature changes by decreasing it, increase retention of soil moisture, to decrease nutrient leaching in the soil profile (Rodrigues et al., 2009; Almeida et al., 2015) increase organic matter and improve chemical characteristics, physical and biological soil properties (Lima et al., 2008). In addition, mulching is capable of increasing water availability (Montenegro et al., 2013), with direct impact on the cycling of nutrients, and is considered an important activity in the sustainability of agricultural systems for the optimization of environmental resources (Chagas et al., 2007), and recommended for semiarid regions (Borges et al., 2014). 
Studies on plant cover on the soil surface have been conducted by several researchers (Carvalho et al., 2011; Santos et al., 2011; Shen et al., 2012; Montenegro et al., 2013; Borges, 2014; Abrantes et al., 2015 ), in order to scientifically validate agroecological practices already widely used in the semiarid. For these scientists, the use of mulching has in fact offered several benefits, among which: increased soil moisture, protection against the direct impact of rain drops, reduction of runoff and water erosion, reduction of soil temperature and lower weed incidence, with increased profitability. Montenegro et al. (2013) investigated the influence of two mulching densities $\left(2\right.$ t.ha $^{-1}$ and 4 t.ha $\left.{ }^{1}\right)$ on surface runoff, soil wetting, and soil warming control.

Borges et al. (2014) evaluated the effects of different types of coverage on the maintenance of soil moisture, under the condition of natural rainfall, as well as the agronomic characteristics of maize (Zea mays L.) under rainfed conditions, and observed that the treatments with mulch contributed significantly to the increase of soil moisture, increasing the infiltration process and the use of rainwater, as well as reducing evaporation loss.

Considering the concept of the agroecosystem, it is considered interesting for the semiarid region of the Northeast to use plants tolerant or resistant to the edaphoclimatic conditions of the region. Oilseeds can be produced at low cost, even in areas that are considered to be less productive, with the possibility of generating employment and income in the field, while also allowing them to take advantage of biodiesel production, which is a source of clean and renewable energy.

Moringa oleifera Lam. is considered an arboreal species that presents high adaptability to climatic conditions and to arid soils (Olson and Fahey, 2011), typical of Brazilian northeastern region (Gualberto et al., 2014). Due to its diverse uses (nutritional, industrial and medicinal), the moringa culture has been disseminated throughout the semiarid region, making it even more attractive, because it is of low production cost and high yield (Silva, 2013). In addition, because it is a perennial crop, it contributes to the maintenance of carbon stocks in the soil, which are released into the atmosphere as a consequence of plowing practices used in short cycle crops.

The objective of this study was to evaluate the impact of the presence and absence of mulching on the height and diameter of non-conventional perennial oilseeds (Moringa oleifera Lam.), characterizing and evaluating the spatial variability of the crops in an alluvial valley in the semiarid of Pernambuco.

\section{Materials and methods}

The study was carried out at the Parnamirim Irrigated Agriculture Station (EAIP), Advanced Campus of the Federal Rural University of Pernambuco, located in the alluvial valley of the Brígida River, a tributary of the São Francisco River, downstream of the Fomento Dam, at coordinates 8'05 '08 "S and 39'34'27" W, located in the municipality of Parnamirim, in the Sertão of Pernambuco (Figure 1).

The region has a tropical semi-arid BShW climate, with annual average rainfall of $515.20 \mathrm{~mm}$ in 2011 (ANA, 2010, APAC, 2011), rainy season beginning in November and ending in April, average yearly temperature is $26.0^{\circ} \mathrm{C}$. Contains as a biome the Caatinga, predominant soil Argiloso / stony, little fertile with risk of salinization.

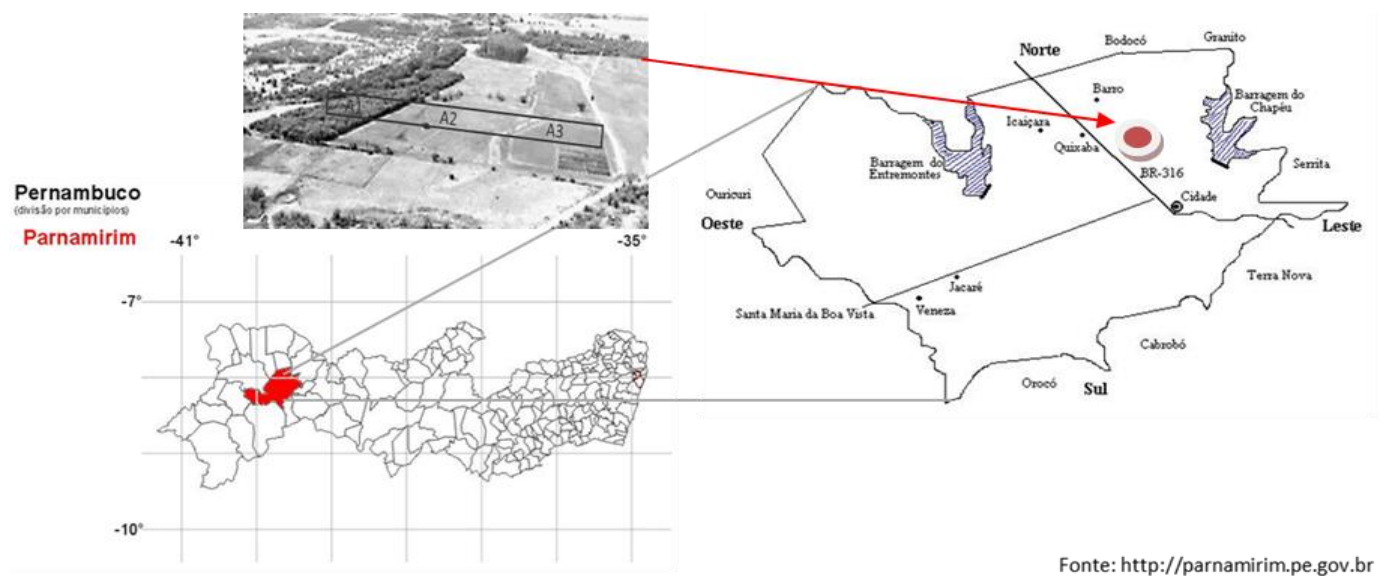

Figure 1 - Map of Pernambuco State, with the location of the municipality of Parnamirim, the Entremontes and Chapéu reservoirs, and the UFRPE Unit. Moringa was established in the A3 area. 


\subsection{Climatic data}

The site meteorological data were acquired from a Campbell Scientific GSW100 Agrometeorological Automatic Station, equipped with sensors and accessories needed to determine reference evapotranspiration (ETo). Data records were from March to June 2017.

The Penman-Monteith method was used to estimate the ETo of the site (equation-1). According to Allenet al., (1998) the Penman-Monteith method parameterized by FAO is considered a standard empirical method to estimate ETo.

\subsection{Conducting the experiment}

Two neighboring irrigated areas were selected, an area containing vegetation conservation practice, using coconut powder (PM) as mulching, whose density was 8 t.ha ${ }^{-1}$, according to Montenegro et al. (2013), and another area with absence of mulching (AM). In both areas, organic fertilization (goat manure) with density of 15 t.ha $^{-1}$ was applied,

$$
\text { ETo }=\frac{0,4080 \Delta\left(R_{n}-G\right)+\gamma \frac{900}{T_{\text {med }}+273} v_{2}\left(e_{s}-e_{a}\right)}{\Delta+\gamma\left(1+0,34 . v_{2}\right)}
$$

Where:

ETo is the reference evapotranspiration in mm.dia ${ }^{-1} ; \mathrm{Rn}$ is the total net radiation of the lawn in MJ $\mathrm{m}^{-2} \cdot \mathrm{d}^{-1} ; \mathrm{G}$ is the soil heat flux density in $\mathrm{MJ} \mathrm{m} \mathrm{m}^{-2} \cdot \mathrm{d}^{-1}$; Tmed is the average daily air temperature in ${ }^{\circ} \mathrm{C} ; \mathrm{v}_{2}$ is the average daily wind speed at $2 \mathrm{~m}$ in $\mathrm{m} . \mathrm{s}^{-1}$; $\mathrm{s}$ is the vapor saturation pressure in $\mathrm{kPa}$; $\mathrm{a}$ is the partial vapor pressure, $\mathrm{kPa} ; \Delta$ - slope of the vapor pressure curve in $\mathrm{kPa} \mathrm{C}{ }^{-1} ; \gamma$ is the psychrometric coefficient, $\mathrm{kPa} \mathrm{C}^{-1}$.

according to Bakkeet al. (2010). In each area, 36 plants were evaluated, totalling 72 plants. The plants are arranged in regular grid of $3 \mathrm{~m} \mathrm{x} 3 \mathrm{~m}$ (Figure 2).

The soil of the study area is characterized as a Flavic Neosol with a clay loam texture. Sand, silt and clay percentages are, respectively, 39.04\%, 43.9\%, $17.06 \%$.

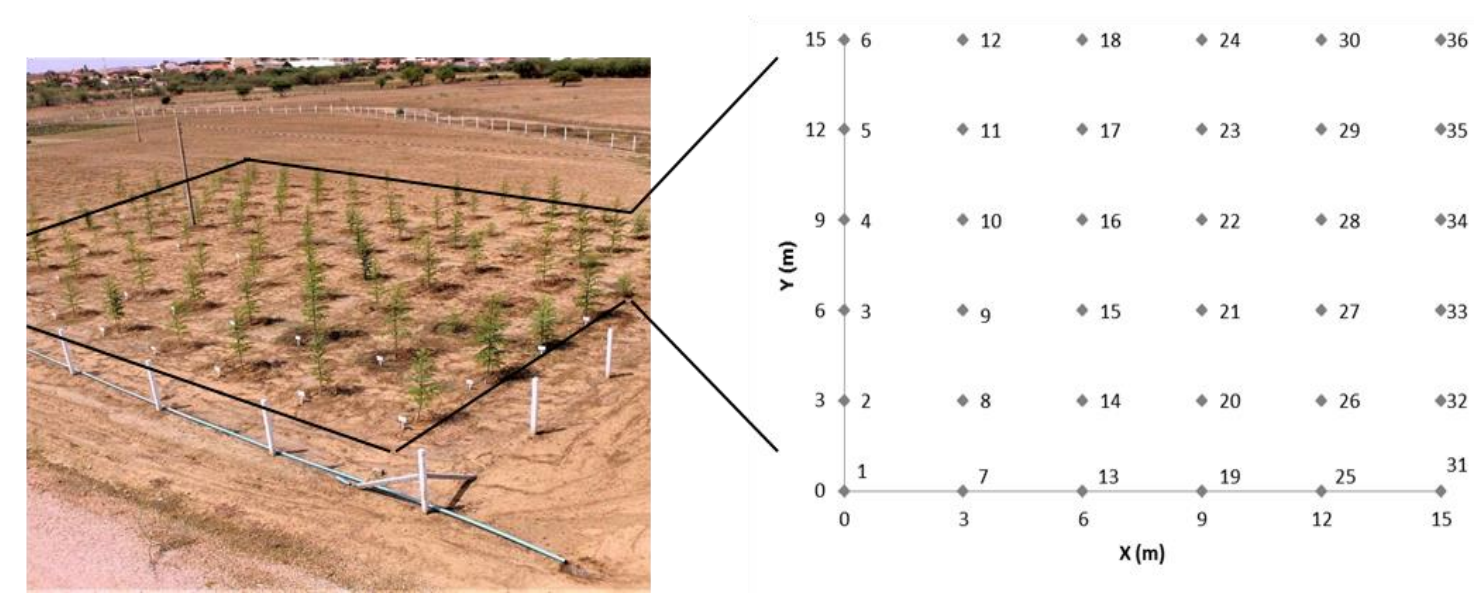

Figure 2 - Scheme of the sampling mesh for areas with presence of mulching (PM) and absence of mulching (AM).

\subsection{Plant Phenological Analyzes}

To estimate the effects of soil mulching application on the Moringa crop, after 324 days of transplanting the following variables were evaluated: plant height and stem diameter. The stem diameter $(\mathrm{mm})$ was determined in the plant's neck at a height of approximately $15 \mathrm{~cm}$, using a digital reading pachymeter. According to Benincasa (2003), the plant height $(\mathrm{cm})$ corresponds to the distance between the base of the stem or colon and the apex of it; in intact plants the soil surface is considered as the lower limit of the length.

\subsection{Descriptive statistics}

The parameters were submitted to descriptive statistics to determine the mean, median, standard deviation, maximum and minimum values, coefficients of asymmetry, kurtosis and coefficient of variation. 
The dispersion and distribution of variables were analyzed by Kolmogorov-Smirnov (KS) normality tests at a $5 \%$ probability level.

The variability of the variables was classified by the coefficient of variation, according to Warrick and Nielsen (1980), where CV $\leq 12 \%$ (low); $12 \leq \mathrm{CV} \leq$ 62 (mean) and $C V \geq 62 \%$ (high).

2.5 Evaluation of spatial dependence and indicative kriging

The spatial dependence analysis was performed using the geostatistics, as described by Vieira (2000) and the semivariogram adjustment. Based on the stationarity hypothesis, semivariogram was calculated through the experimental semivariances $\gamma$ (h), estimated by equation 2 :

$$
\hat{\gamma}(\mathrm{h})=\frac{1}{2 \mathrm{~N}(\mathrm{~h})} \sum_{\mathrm{i}-1}^{\mathrm{N}(\mathrm{h})}\left[\mathrm{z}\left(\mathrm{x}_{\mathrm{i}}\right)-\mathrm{z}\left(\mathrm{x}_{\mathrm{i}}+\mathrm{h}\right)\right]^{2}
$$

\section{Where:}

$\gamma$ (h) are the semivariance and $N(h)$ is the number of pairs at each distance $\mathrm{h} . \mathrm{Z}\left(\mathrm{x}_{\mathrm{i}}\right)$ and $\mathrm{Z}\left(\mathrm{x}_{\mathrm{i}}+\mathrm{h}\right)$ are estimates separated by a $\log$ distance $h$.

Adjustments of the mathematical models and definition of the parameters for semivariograms were performed: a) nugget effect $(\mathrm{C} 0)$; b) extent of spatial dependence $(\mathrm{a})$; c) threshold $(\mathrm{C} 0+\mathrm{C} 1)$. The gaussian, spherical and exponential models were analyzed, respectively, selecting the one that best represents the experimental spatial variation structure of the variables.

The degree of spatial dependence (GDE) was evaluated according to Cambardella et al.

(1994), which is based on the percentage proportion of the nugget effect $(\mathrm{C} 0)$ in relation to the level $(\mathrm{C} 0+$ $\mathrm{C} 1$ ), classified as: (a) strong dependence $<25 \%$; (b) moderate dependence between 25 and $75 \%$ and (c) weak dependence> $75 \%$, calculated by equation 3 :

$$
\mathrm{GDE}=\left(\frac{\mathrm{C}_{\mathrm{o}}}{\mathrm{C}_{0}+\mathrm{C}}\right) \times 100
$$

For the generation of the spatial maps and visualization of the spatial distribution, Surfer software (SURFER, 2002) was adapted.

2.6 Analysis of variance of uncorrelated variables in space

Analysis of variance was applied to data with at distances greater than those defined by the range. The experimental design was completely randomized, and the treatments were considered based on the areas with PM and AM, with different numbers of repetitions.

According to Vieira (2000), points collected with distance greater than the range (a) of the semivariogram can be analyzed by classical statistics.

\section{Results and discussion}

Figure 3 shows the temporal behavior of precipitation totals, mean temperature values, as well as monthly reference evapotranspiration in the period from March to June 2017. It is observed that the highest rainfall indexes were concentrated in the months of April $(66.30 \mathrm{~mm})$ and March $(23.622 \mathrm{~mm})$; while May and June presented the lowest total precipitation, of $18.28 \mathrm{~mm}$ and $19.81 \mathrm{~mm}$, respectively. March presented the highest evapotranspiration rate (4.61 mm.d ( $^{-1}$ ).

The values corresponding to the height (HP) and stem diameter (SD) of the Moringa oilseeds were submitted to the descriptive statistics analysis. Table 1 shows the values of the statistical parameters used to describe the distributions of the measured data. The observed data had the coefficients of asymmetry and kurtosis close to zero, showing that the variables present distribution close to Normal, and the CVs presented mean values, according to the criteria of Warrick and Nielsen (1980). 


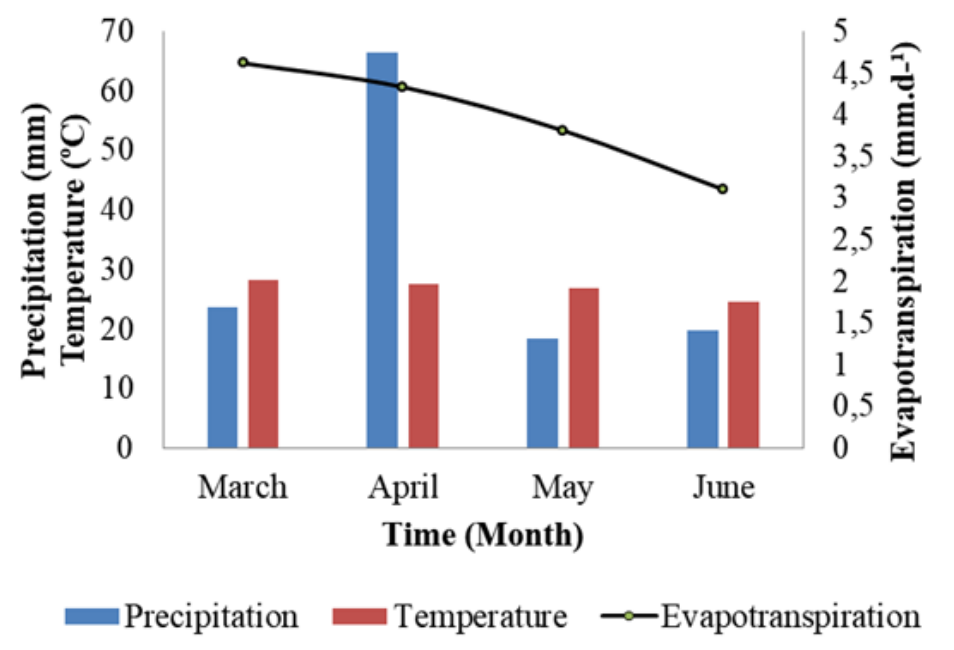

Figure 3 - Precipitation values $(\mathrm{mm})$; Temperature $\left({ }^{\circ} \mathrm{C}\right)$ and Evapotranspiration $\left(\mathrm{mm} \cdot \mathrm{d}^{-1}\right)$ of the study site, from March to June 2017.

Table 1 - Statistical parameters for the variables plant height $(\mathrm{cm})$ and stem diameter $(\mathrm{mm})$ Moringa oleifera Lam under the presence and absence of mulching.

\begin{tabular}{|c|c|c|c|c|}
\hline \multirow{2}{*}{ Parameters } & \multicolumn{2}{|c|}{ 1PM } & \multicolumn{2}{|c|}{${ }^{2} \mathrm{AM}$} \\
\hline & ${ }^{3} \mathrm{HP}$ & ${ }^{4} \mathrm{SD}$ & ${ }^{3} \mathrm{HP}$ & ${ }^{4} \mathrm{SD}$ \\
\hline Average & 294.9 & 48.2 & 258.6 & 43.0 \\
\hline${ }^{5} \mathrm{DP}$ & 55.7 & 8.3 & 54.5 & 8.4 \\
\hline${ }^{6} \mathrm{KS} \mathrm{5 \%}$ & 0.23 & 0.23 & 0.23 & 0.23 \\
\hline Maximum error & 0.15 & 0.15 & 0.12 & 0.15 \\
\hline Medium & 300.0 & 47.5 & 270.0 & 44.0 \\
\hline Minimum & 170.0 & 30.0 & 160.0 & 26.0 \\
\hline Maximum & 370.0 & 69.0 & 340.0 & 65.0 \\
\hline Amplitude & 200.0 & 39.0 & 180.0 & 39.0 \\
\hline${ }^{7} \mathrm{CV} \%$ & 18.9 & 17.20 & 21.08 & 19.42 \\
\hline Variance & 3105.71 & 68.8 & 2972.06 & 70.02 \\
\hline Curtose & -0.19 & -0.12 & -0.09 & 0.69 \\
\hline Asymmetry & -0.72 & 0.23 & -0.44 & -0.03 \\
\hline
\end{tabular}

Completing the analyzes of the data distributions (Figure 4), the "Box plot" graph presented in Figure 5 was elaborated, allowing to verify the symmetry of the data distributions, in relation to the median; however, it is noted that the readings performed in the treatment with presence of mulching tend to be higher than the readings performed in the treatment with mulching, and the standard deviation presents a relative similarity between readings. It can be observed that there were discrepant values in the data referring to the diameter of plants with absence of mulching in the soil. 

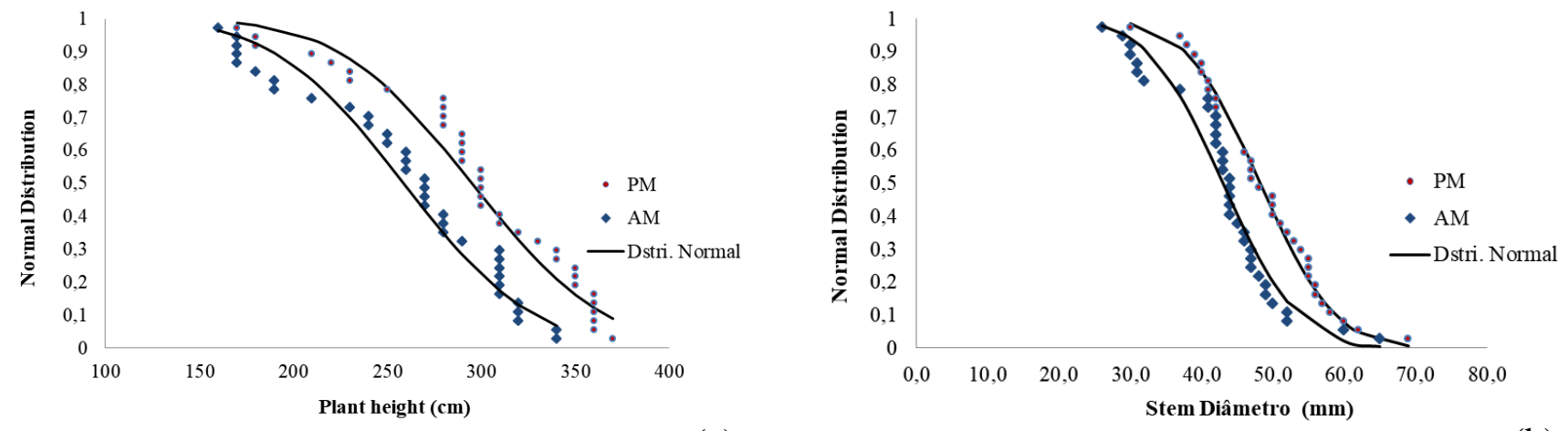

(a)

Figure 4 - Normal probability graphs for the variables plant height (a) and stem diameter (b) Moringa oleaginous presence and absence of mulching.
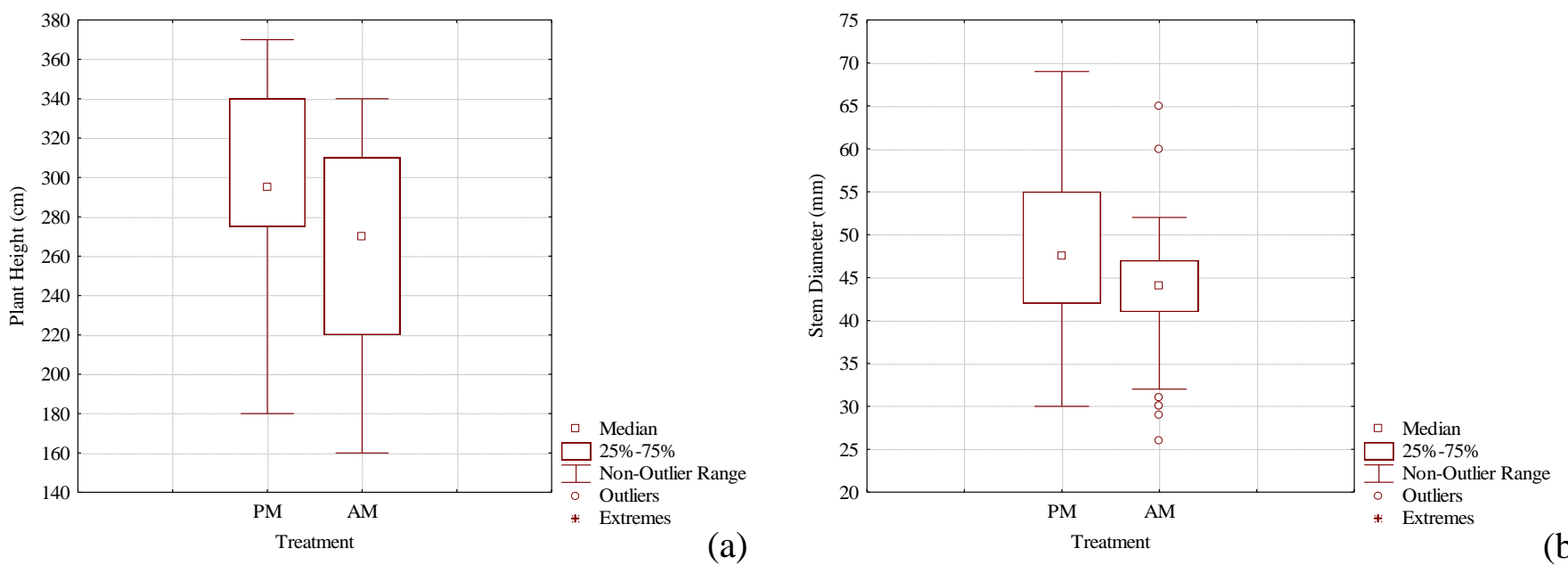

Figure 5 - Box-plot of the variable plant height (a) and stem diameter (b) Moringa oleifera Lam with presence and absence of mulching.

Table 2 presents the averages of the phenological parameters performed due to the presence and absence of mulching. According to the Tukey test, the averages had a significant effect $(\mathrm{P}<0.05)$, thus

verifying the influence of mulching on plant growth. Borges et al. (2014) observed that stem height and basal stem diameter in corn (Zeamays L.) showed a significant increase with mulching treatment.

Table 2 - Mean of the phenological parameters of the Moringa oleifera Lam oilseeds with presence and absence of mulching.

\begin{tabular}{ccc}
\hline Treatments & Height $(\mathbf{c m})$ & Diameter $(\mathbf{m m})$ \\
\hline PM & $282.0 \mathrm{a}$ & $46.4 \mathrm{a}$ \\
AM & $204.0 \mathrm{~b}$ & $37.6 \mathrm{a}$ \\
\hline CV $(\%)$ & 14.98 & 14.49
\end{tabular}

Means followed by equal letters in the columns do not differ among themselves by the Tukey test $(\mathrm{p}<0.05)$;

The use of mulching benefited the crop development, favoring improvements in soil quality. Paiva and Araújo (2012) verified that the use of mulching prevents excessive loss of soil water by evaporation, thus contributing to adequate conditions for the development of plants. Montenegro et al. (2013) found that when using mulch, there were reductions in the peak flow, and that high vegetation cover rates resulted in a significant increase in soil moisture. In addition, the soil temperature was optimally regulated under a mulching density of 4 t.ha ${ }^{-1}$. 
The mean of the stem diameter variable in the treatments, according to the Tukey test, identified that the soil cover had no significant effect $(\mathrm{P}<0.05)$, that is, from the statistical point of view, PM treatment did not differ from AM treatment. Figure 6 shows the means and standard deviations for the analyzed variables.

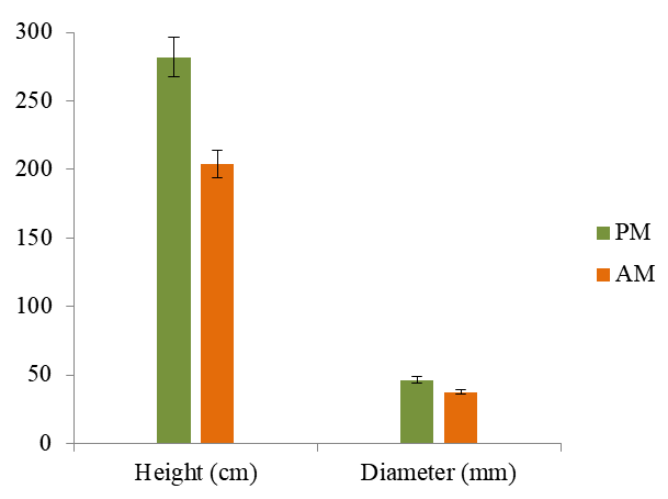

Figure 6 - Classical parameters for plant height and Moringa Lam oilseeds stem diameter, with presence and absence of mulching.

The variables such as soil moisture and temperature may have influenced the growth of the plant, since when the treatment with absence of mulching was observed, there was a reduction in the values of the parameters. According to Borges et al. (2014), the reduction in plant growth is considered a consequence of a defense mechanism in water stress conditions, because it reduces water losses by plants.

Menezes et al. (2013) point out that evapotranspiration favors the decrease of the water content of the soil in the condition of natural cover in the drought period, making these values lower than the soil moisture in the condition of uncovered soil.
Based on cross-validation, we selected the semivariogram models that best fit the distribution of experimental semivariance (Table 3). The Spherical model was the one that adequately adjusted the variables. The stepped semivariograms can be seen in Figures 7. The degree of spatial dependence (GDE) shows that there is a strong $(<25 \%)$ dependence on plant height and stem diameter with PM treatment, whereas AM treatments showed moderate and strong dependence, respectively, for height and diameter. That is, the presence of the mulching increased the spatial dependence of the height variable.

Table 3 - Models, parameters of experimental semivariogram and cross-validation for plant height (HP) and stem diameter (SD) for Moringa oleifera Lam oilseed crop in presence (PM) and absence (AM) of mulching.

\begin{tabular}{|c|c|c|c|c|}
\hline & \multicolumn{2}{|c|}{$\mathrm{PM}$} & \multicolumn{2}{|c|}{$\mathrm{AM}$} \\
\hline & $\mathrm{HP}$ & SD & $\mathrm{HP}$ & SD \\
\hline $\mathrm{C} 0$ & 0.185 & 0.162 & 1778.37 & 14.79 \\
\hline $\mathrm{C} 0+\mathrm{C}$ & 2028.18 & 60.16 & 3139,00 & 66.75 \\
\hline $\mathrm{a}$ & 6.71 & 10.10 & 4.93 & 4.08 \\
\hline Model & Spherical & Spherical & Spherical & Spherical \\
\hline $\operatorname{GDE}(\%)$ & 0.01 & 0.30 & 56.65 & 22.15 \\
\hline \multirow[t]{2}{*}{ Classification } & FT & FT & MD & FT \\
\hline & \multicolumn{4}{|c|}{ Cross-validation parameters } \\
\hline Average of Errors & -0.20 & -0.38 & -0.001 & -0.015 \\
\hline DP & 1.363 & 2.243 & 0.997 & 1.013 \\
\hline $\mathrm{R}^{2}$ & 0.30 & 0.31 & 0.61 & 0.30 \\
\hline
\end{tabular}

C0: Nugget effect; C0 + C: Sill; a: Range; GDE: Degree of spatial dependence; R²: Semivariogram adjustment; SD: Reduced error standard deviation; FR: Weak; FT: Strong; MD: Moderate. 

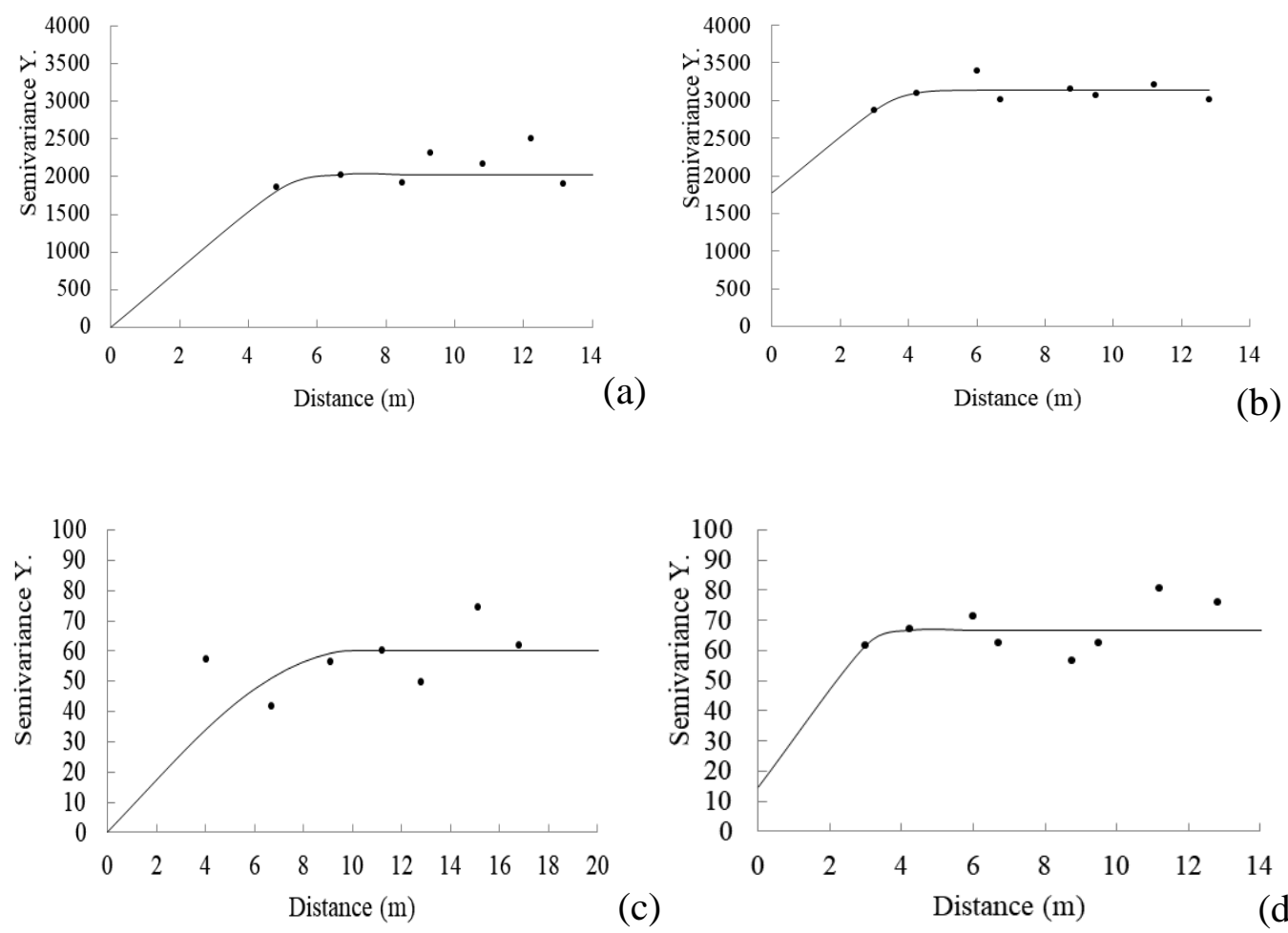

Figure 7 - Semivariograms of the parameters: Height of the plant with presence of mulching (a); Plant height with absence of mulching (B); Stem diameter with presence of mulching (C); Stem diameter with of mulching (D).

In order to make it possible to visualize the spatial distribution of parameter values, we generated maps of isolines that are shown in Figure 8. It can be noticed a correlation between plant height and stem diameter, that is, the larger the region that contains more plants, the larger the diameter of the plant, the higher the occurrence of tall plants in the central region of the area, for PM treatment. The central rectangle highlights the planting regions with less influence of the border, where it is more evident the relevance of the mulching in the variable height of the Moringa. Silva et al. (2010) identified regions with greater growth of the crop using mapping tool of plant height and stem diameter.

Therefore, it was observed that the values obtained from the agronomic characteristics were differentiated due to the presence and absence of the conservation practices, in the treatments analyzed, evidencing that the use of the practice becomes advantageous for the cultivation of Moringa, in relation to the height of the plant. According to Silva et al. (2014), who used mulching in the study area as a conservationist practice, they observed that all the growth variables showed a significant difference to mulching and obtained a better performance in the castor bean growth.

The planting of Moringa oleifera Lam. can be considered an alternative for small farmers, in the context of agroecological systems, using conservation practices, and mitigate climate change, by improving soil quality. It also enables the generation of employment and income in the field, using seed production to generate biodiesel, which is a source of clean and renewable energy available to family farmers. 

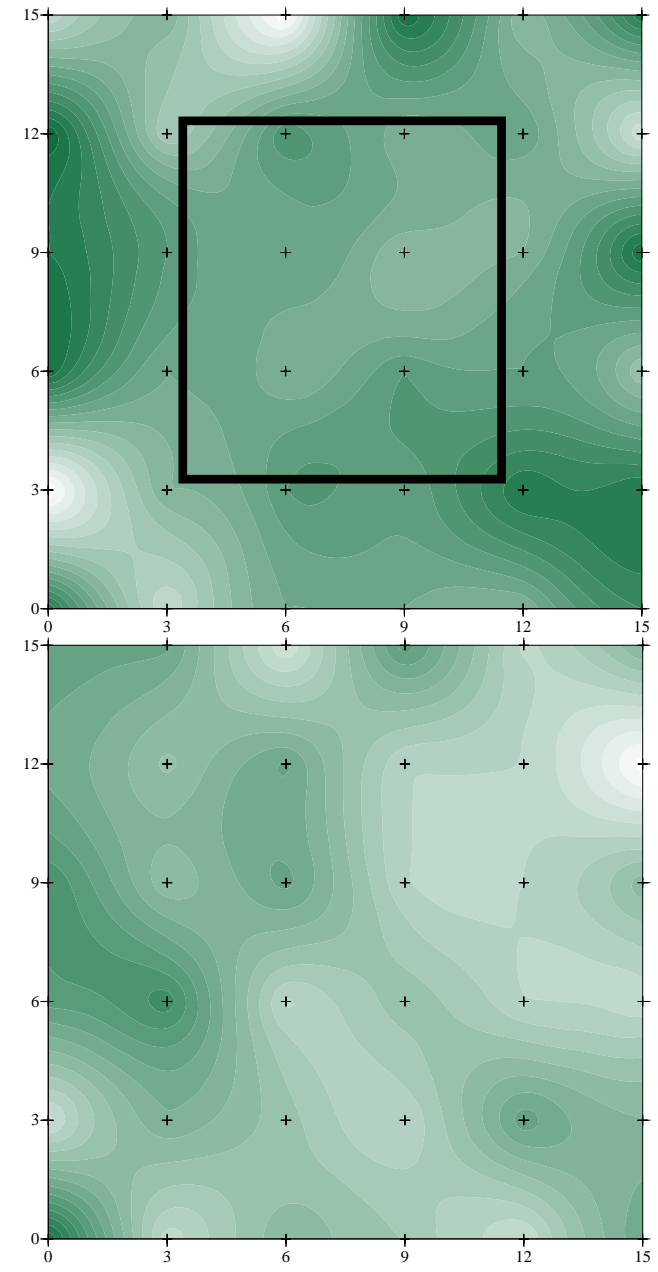

(a)
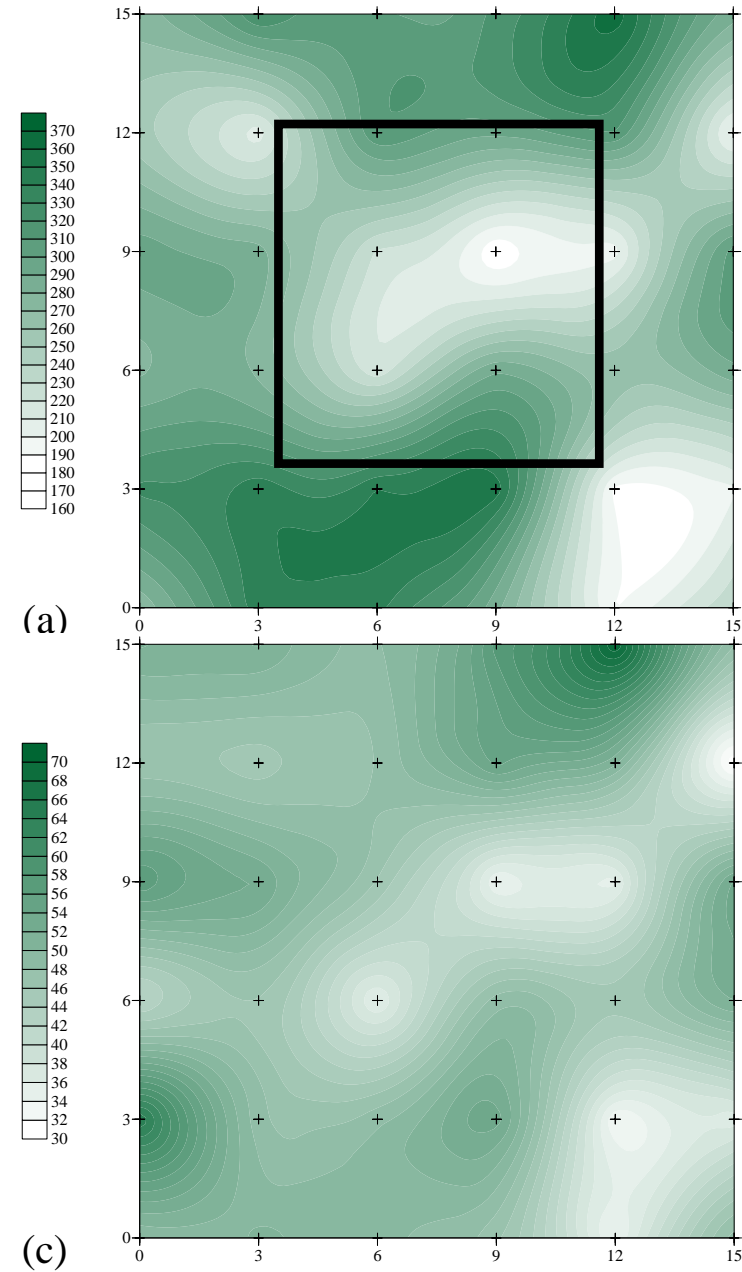

(b)

(c)

Figure 8 - Map for the parameters: Height of the plant with presence of mulching (a); Plant height with absence of mulching (B); Stem diameter with presence of mulching (C); Stem diameter with of mulching (D).

\section{Conclusions}

-The mean values of the plant height diameters with PM showed the highest values in relation to the AM; There was strong dependence on the heights of plants in both treatments;

- The presence with mulching treatments, both for height and diameter, showed strong spatial dependence;

- Removing the border region, the mulching provided a significant increase in the height of the moringa;

- In general, the use of conservation practice with the application of mulching promoted agronomic improvement, which possibly led to more favorable conditions to the development of the Moringa oleifera Lam planting, regarding the height of the plant, helping to mitigate the climatic change impacts.

\section{Acknowledgments}

The authors thank the CNPq (PVE-400757 / 2013-3), the Foundation for the Support of Science of the State of Pernambuco (FACEPE) for financial support for studies and the Postgraduate Program in Agricultural Engineering (PGEA) Federal Rural of Pernambuco (UFRPE). Special thanks to the Coordinator of the Experimental Unit of UFRPE (Mr. Eurico Lustosa), and to the technician Edson Abrantes, for the support to carry out this work.

\section{References}

Abrantes, J.R.C.B., Lima, J.L.M.P., Montenegro, A.A.A., 2015. Desempenho da modelagem cinemática do escoamento superficial para chuvas intermitentes em solos com cobertura morta. Revista Brasileira de Engenharia Agrícola e Ambiental 19, 166-172.

Allen, R.G., Pereira, L.S., Raes, D., Smith, M., 1998. Crop evapotranspiration: guidelines for computing 
crop water requirements. FAO, Rome. (Irrigationand Drainage Paper, 56)

Almeida, D.J.de, Cavalcante, L.F., Silva, R.A.R.da, Araújo, R.daC., Silva, V.B.da, Malta, A.O., 2015. Irrigação de salvação e cobertura do solo no rendimento de gravioleira 'morada' em safras consecutivas. Pesquisa Agropecuária Pernambucana 20, 11-16.

Almeida, A.Q., Souza, R.M.S., Silva, S.M.S., Oliveira Junior, I.S., Cavalcante, F.S., Melo, J.A.S., 2016. Space-time dependence of jatropha growth parameters grown in Brazilian semiarid. Revista Caatinga 29, 358-366.

ANA. Agência Nacional de Águas, 2010. Atlas de Abastecimento Urbano de Água. Sistema Nacional de Informação sobre Recursos Hídricos, Brasília.

APAC. Agência Pernambucana de Águas e Climas, 2011. Climatologia de Precipitação. Recife. (Boletim Pluviométrico 2011).

Bakke, I.A., Souto, J.S., Souto, P.C., Bakke, O.A., 2010. Características de crescimento e valor forrageiro da moringa (Moringa oleifera lam.) submetida a diferentes adubos orgânicos e intervalos de corte. Revista Engenharia Ambiental 7, 133-144.

Benincasa, M.M.P., 2003. Análise de Crescimento de Plantas: noções básicas. FUNEP, Jaboticabal.

Borges, T.K.S., Montenegro, A.A.A., Santos, T.E.M., Silva, D.D., Silva Junior, V.P., 2014. Influência de práticas conservacionistas na umidade do solo e no cultivo do milho (Zeamays L.) em semiárido nordestino. Revista Brasileira de Ciência do Solo 38, 1862-1873.

Cambardella, C.A., Moorman, J.M., Novak, T.B., Karlen, D.L., Turco, R.F., Konopka, A.E., 1994. Field-scale variability of soil properties in Central Iowa Soils. Soil Science Society of America Journal 58, 1501-1511.

Carvalho, J.F., Montenegro, A.A.A., Soares, T.M., Silva, E.F.F., Montenegro, S.M.G.L., 2011. Produtividade do repolho utilizando cobertura morta e diferentes intervalos de irrigação com água moderadamente salina. Revista Brasileira de Engenharia Agrícola e Ambiental 15, 256-263.

Ceddia, M.B., Villela, A.L.O., Pinheiro, É.F.M., Wendroth, O., 2015. Spatial variability of soil carbon stock in the Urucu river basin, Central Amazon-Brazil. The Science of the Total Environment 526, 58-69.

Chagas, E., Araújo, A.P., Teixeira, M.G., Guerra, J.G.M., 2007. Decomposição e liberação de nitrogênio, fósforo e potássio de resíduos da cultura do feijoeiro. Revista Brasileira de Ciência do Solo 31, 723-729.

Fontes Júnior, R.V.P., Montenegro, A.A.A., Montenegro, S.M.G.L., Santos, T.E.M., 2012. Estabilidade temporal da potenciometria e da salinidade em vale aluvial no semiárido de Pernambuco. Revista Brasileira de Engenharia Agrícola e Ambiental 16, 1188-1197.

Gualberto, A.F., Ferrari, G.M., Abreu, K.M.P., Preto, B.L., Ferrari, J.L., 2014. Características, propriedades e potencialidades da moringa (Moringa oleifera Lam.): Aspectos agroecológicos. Revista Verde de Agroecologia e Desenvolvimento Sustentável 9, 19-25.

Lal, R., 2011. Carbon sequestration in soil in agroecosystems. Food Policy 36, Supplement 1, S33S39.

Lima, J.L., Resende, F.V., Souza, R.B.de, Guimarães, M.O., 2008. Adubação com composto de farelos anaeróbico na produção de tomate orgânico cultivado sobre coberturas vivas de amendoim forrageiro e grama batatais. Revista Horticultura Brasileira 26, 191-194.

Melo, R.O., Montenegro, A.A.A., 2015. Dinâmica temporal da umidade do solo em uma bacia hidrográfica no semiárido Pernambucano. Revista Brasileira Recursos Hídricos 20, 430-441.

Menezes, J.A.L., Santos, T.E.M., Montenegro, A.A.A., SILVA, J.R.L., 2013. Comportamento temporal da umidade do solo sob Caatinga e solo descoberto na Bacia Experimental do Jatobá, Pernambuco. Water Resources and Irrigation Management 2, 45-51.

Montenegro, A.A.A., Abrantes, J.R.C.B., Lima, J.L.M.P., Singh, V.P., Santos, T.E.M., 2013. Impact of mulching on soil and water dynamics under intermittent simulated rainfall. Catena 109, 139149.

Olson, M.E., Fahey, J.W., 2011. Moringa oleifera: unárbol multiusos para las zonas tropicales secas. Revista Mexicana de Biodiversidad 82, 1071-1082.

Paiva, A.Q., Araújo, Q.R., 2012. Fundamentos do manejo e da conservação dos solos na região produtora de cacau da Bahia, in: Valle, R.R. (Ed.), Ciência, Tecnologia e Manejo do Cacaueiro. 2.ed. Ceplac/CEPEC/SEFIS, Brasília, pp. 115-134.

Rodrigues, D.S., Nomura, E.S., Garcia, V.A., 2009. Coberturas de solo afetando a produção de alface em sistema orgânico. Revista Ceres 56, 332-335.

Santos, D., Souza, E.G., Nóbrega, L.H.P., Bazzi, C.L., Gonçalves Júnior, A.C., 2012. Variabilidade espacial de atributos físicos de um Latossolo Vermelho após cultivo de soja. Revista Brasileira de Engenharia Agrícola e Ambiental 16, 843-848. 
Santos, T.E.M., Montenegro, A.A.A., Silva, D.D., 2011. Umidade do solo no semiárido pernambucano usando-se reflectometria no domínio do tempo (TDR). R. Revista Brasileira de Engenharia Agrícola e Ambiental 15, 670-679.

Shen, J.Y., Zhao, D.D., Han, H.F., Zhou, X.B., LI, Q.Q., 2012. Effects of straw mulching on water consumption characteristics and yield of different types of summer maize plants. Plant, Soil and Environment 58, 161-166.

Silva, E.C.A., 2013. Respostas fisiológicas, bioquímicas e enzimáticas em mudas de Moringa oleifera Lam. submetidas a estresses abióticos. Dissertação (Mestrado). Recife, UFRPE.

Silva, J.J.N., Montenegro, A.A.A., Pedrosa, E.M.R., Beltrão, N.E.M., Henrique, H.M., 2014. Water allocations and mulching in castor bean crops in a semiarid Fluvic Neossol. Revista Ciência
Agronômica 45, 443-452.

Silva, J.J.N., Montenegro, A.A.A., Silva, E.F.F., Fontes Júnior, R.V.P., Silva, A.P.N., 2010. Variabilidade espacial de parâmetros de crescimento da mamoneira e de atributos físico-químicos em Neossolo. Revista Brasileira Engenharia Agrícola Ambiental 14, 921-931.

SURFER, 2002. SURFER 8.0: Contouring and 3d surface mapping for scientists and engineers. User'sGuide. Golden Software, New York.

Vieira, S.R., 2000. Geoestatística em estudos de variabilidade espacial do solo, in: Novais, R.F. et al. (Ed.). Tópicos em Ciência do Solo. SBCS, Viçosa, pp. 1-54.

Warrick, A.W., Nielsen, D.R., 1980. Spatial variability of soil physical properties in the field, in: Hillel, D. (Ed.). Applications of Soil Physics. Academic, New York, pp. 319-344. 